\title{
PENGEMBANGAN MULTIMEDIA BERBASIS ANDROID UNTUK KOMPETENSI DASAR PENGUKURAN LISTRIK DI SEKOLAH MENENGAH KEJURUAN
}

\author{
Vivi Melina Sari ${ }^{1}$, Edy Supriyadi ${ }^{2}$, Faranita Surwi ${ }^{3}$ \\ ${ }^{1}$ Jurusan Pendidikan Teknik Elektro, Fakultas Teknik, Universitas Negeri Yogyakarta \\ email : vivimelina.bw@gmail.com
}

\begin{abstract}
The purposes of this research are: (1) to know the performance of android based multimedia which is developed as learning media for basic competence of electrical measurment; (2) to know feasibility level of the multimedia developed evaluated on material and learning media aspect; (3) to know user response of the multimedia. This research is RnD (Research and Development) with ADDIE method. The results of this research showed that: (1) the performance of the media is "Very Good", (2) the feasibility of multimedia is "Highly Feasible", (3) according to the users, the multimedia is categorized as "Feasible".
\end{abstract}

Keywords: Multimedia, Android, ADDIE, Electrical Measurment.

\begin{abstract}
ABSTRAK
Penelitian ini bertujuan untuk: (1) mengetahui unjuk kerja multimedia berbasis android yang dikembangkan sebagai media pembelajaran untuk kompetensi dasar pengukuran listrik; (2) mengetahui tingkat kelayakan multimedia berbasis android sebagai media pembelajaran untuk kompetensi dasar pengukuran listrik ditinjau dari aspek materi dan aspek media pembelajaran; (3) mengetahui tanggapan pengguna terhadap multimedia berbasis android yang dikembangkan sebagai media pembelajaran untuk kompetensi dasar pengukuran listrik. Penelitian ini menggunakan jenis penelitian RnD (Research and Development). Model pengembangan penelitian menggunakan ADDIE. Hasil penelitin menunjukkan bahwa: (1) unjuk kerja produk yang dihasilkan secara keseluruhan dikategorikan "Sangat Baik"; (2) kelayakan multimedia interaktif berbasis android yang dikembangkan sebagai media pembelajaran untuk kompetensi dasar pengukuran listrik dari aspek materi dikategorikan "Layak", sedangkan kelayakan ditinjau dari aspek media dikategorikan "Sangat Layak";

(3) tanggapan pengguna terhadap multimedia berbasis android yang dikembangkan sebagai media pembelajaran untuk mata pelajaran untuk kompetensi dasar pengukuran listrik dikategorikan "Layak".
\end{abstract}

Kata kunci: Multimedia, Android, ADDIE, Pengukuran listrik.

\section{PENDAHULUAN}

Pendidikan terdiri atas pendidikan non formal dan formal. Pelaksanaan pendidikan non formal cenderung fleksibel karena tidak terikat pada struktur dan jenjang, sedangkan pendidikan formal dilaksanakan secara terstruktur dengan urutan yang jelas mulai dari pendidikan dasar, pendidikan menengah, hingga pendidikan tinggi. Pendidikan formal juga dibagi menjadi dua jenis yaitu umum dan kejuruan. Salah satu jenis pendidikan menengah yang bersifat kejuruan adalah Sekolah Menengah Kejuruan (SMK).

Sesuai Peraturan Pemerintah Republik Indonesia Nomor 29 Tahun 1990 tentang Pendidikan Menengah, Pendidikan kejuruan adalah pendidikan pada jenjang pendidikan menengah yang mengutamakan pengembangan kemampuan peserta didik untuk melaksanakan jenis pekerjaan tertentu. Kemampuan yang dimiliki peserta didik menjadi tolak ukur tercapainya tujuan pendidikan. Menurut Blooms sebagaimana dikutip oleh Tung (2017: 
125), tujuan pendidikan peserta didik berdasarkan kemampuannya dibagi ke dalam tiga kelompok yaitu ranah kognitif, ranah afektif, dan ranah psikomotorik. Setiap kelompok mempunyai ciri khas masing-masing yang dapat membedakan ketercapaian tujuan tersebut. Ranah kognitif bertujuan untuk mengasah kemampuan yang menekankan pada aspek intelektual yang meliputi: pengetahuan, penafsiran, pengaplikasian, penguraian, pemaduan, dan penilaian. Ranah afektif bertujuan untuk mengasah kemampuan yang menekankan pada aspek emosional seperti perasaan, nilai, penghargaan, semangat, kecenderungan, motivasi, dan perilaku. Ranah psikomotorik bertujuan mengasah kemampuan yang mengutamakan aspek keterampilan motorik/kemampuan fisik untuk mempraktikan sesuatu.

Pengembangan kemampuan peserta didik termasuk di SMK dipengaruhi antara lain oleh metode dan media yang digunakan saat melakukan proses pembelajaran. Menurut Muhibbinsyah sebagaimana dikutip dalam oleh Sugihartono (2015:77) terdapat beberapa hal yang berpengaruh terhadap kegiatan belajar, salah satunya adalah cara atau metode yang digunakan untuk memahami materi pelajaran. Kartikasari (2016: 63) berpendapat bahwa untuk mencapai tujuan pembelajaran sangat diperlukan suatu media yang dapat mengembangkan kemampuan peserta didik dalam kegiatan belajar. Beberapa pendapat di atas mengarah pada suatu kesimpulan bahwa pengembangan kemampuan peserta didik antara lain dipengaruhi oleh metode dan media belajar. Metode digunakan sebagai penyesuaian dengan karakteristik peserta didik. Media pembelajaran digunakan sebagai media untuk mempermudah kegiatan belajar mengajar.

Guru dalam menggunakan media pembelajaran harus disertai dengan metode yang inovatif supaya tidak menimbulkan kejenuhan bagi peserta didik. Amir \& Apriani (2011: 14) berpendapat guru yang hanya berbekal literatur di dalam kelas akan kurang diapresiasi oleh peserta didik, sedangkan guru yang inovatif dalam penyampaian materi akan disegani oleh peserta didik. Jadi, guru dituntut menyampaikan materi dengan cara yang inovatif berbekal media pembelajaran yang digunakan, misalnya dengan cara melibatkan unsur teknologi ke dalam media pembelajaran. Tujuannya adalah agar peserta didik lebih fokus dalam mempelajari materi pelajaran.

Salah satu contoh SMK yang menyelenggarakan jenjang pendidikan sekolah menengah kejuruan teknologi adalah SMK Nasional Berbah. SMK Nasional Berbah beralamat di Tanjungtirto, Kalitirto, Berbah, Sleman. Sebagai SMK yang berbasis teknologi, pembelajaran yang ada di SMK Nasional Berbah harus disesuaikan dengan perkembangan teknologi, termasuk media belajar yang digunakan. Berdasarkan hasil observasi selama Praktik Lapangan Persekolah (PLP) media pembelajaran teori yang digunakan di SMK Nasional Berbah khususnya pada Kompetensi Keahlian Teknik Instalasi Tenaga Listrik (TITL) masih kurang interaktif. Salah satu contohnya adalah media pembelajaran untuk kompetensi dasar pengukuran listrik (DLE). Penggunaan LCD proyektor dan papan tulis sebagai media pembelajaran menjadikan proses pembelajaran tidak menarik, hal tersebut membuat peserta didik jenuh dengan materi yang disampaikan. Sesuai dengan Keputusan Direktur Jenderal Pendidikan Dasar dan Menengah Nomor 330/D.D5/KEP/KR/2017, Kompetensi Dasar (KD) yang harus dikuasai peserta didik pada mata pelajaran DLE berupa penggunaan alat ukur listrik untuk mengukur besaran tahanan, arus, tegangan, daya, energi listrik, dan faktor daya. Agar KD tersebut dapat dikuasai oleh peserta didik dengan baik diperlukan media pembelajaran yang lebih interaktif yang dilengkapi simulator untuknmata pelajaran DLE.

Hasil observasi peneliti juga menunjukkan fakta bahwa keaktifan peserta didik masih rendah. Peserta didik cenderung 
jenuh dengan penyampaian materi yang kurang menarik. Penyampaian yang kurang menarik dapat mengakibatkan peserta didik kurang mengapresiasi guru pada saat menyampaikan materi. Dengan demikian peserta didik memilih mengoperasikan smartphone android saat pembelajaran. Penyebabnya adalah tidak adanya media pembelajaran yang tepat untuk mendukung mata pelajaran DLE. Peran guru selama proses pembelajaran juga masih kurang. Peserta didik hanya diberi tugas untuk mencari materi melalui smartphone android. Hal ini menyebabkan capaian kompetensi peserta didik pada mata pelajaran DLE masih rendah.

Berdasarkan hasil wawancara dengan Drs. Priyo Handoko selaku guru Jurusan TITL SMK Nasional Berbah, motivasi dan minat belajar peserta didik di SMK Nasional Berbah lebih rendah dari pada di SMK Negeri. Penyebabnya peserta didik merasa mata pelajaran khususnya DLE yang disampaikan abstrak, karena listrik merupakan sesuatu yang tidak kelihatan namun bisa dirasakan. Begitupun kurangnya media pembelajaran yang dapat disimulasikan secara langsung, sehingga peserta didik hanya diberi teorinya saja. Beliau juga mengatakan bahwa di SMK Nasional Berbah tidak ada peraturan melarang peserta didik membawa smartphone. Karena dirasa dengan adanya perkembangan teknologi sekarang ini peserta didik dapat memanfaatkan smartphone sebagai sumber belajar yang efektif. Oleh karena itu peserta didik dapat menggunakan smartphone saat proses pembelajaran sebagai sumber belajar di kelas.

Permasalahan di atas tidak hanya terjadi di SMK Nasional Berbah, tetapi bisa juga terjadi di SMK lain yang mengalami keterbatasan media pembelajaran. Maka dari itu perlu dilakukan penelitian untuk mengembangkan media pembelajaran untuk Kompetensi Dasar pengukuran listrik. Konsep media yang dikembangkan adalah multimedia yang dapat dioperasikan menggunakan android. Pemilihan multimedia berbasis android sebagai media yang dikembangkan bertujuan untuk membuat proses pembelajaran menjadi interaktif, tidak membosankan, serta multimedia ini dilengkapai dengan simulator pengukuran yang berfungsi untuk memudahkan peserta didik dalam memahami materi yang tidak sebatas teori, melainkan berupa simulator untuk merangsang kemampuan visualisasi peserta didik.

\section{METODE}

Penelitian ini merupakan jenis penelitian dan pengembangan (research and development). Model pengembangan yang digunakan yaitu model pengembangan ADDIE menurut Lee dan Owens. Model pengembangan Lee dan Owens terdiri dari lima tahapan yaitu:

(1) Penilaian dan analisis kebutuhan (Assessment and analysis); (2) desain (design); (3) Pengembangan (development);

Implementasi (Implementation) dan;

Evaluasi (evaluation).

\section{HASIL DAN PEMBAHASAN}

Hasil analisis data ahli materi didapatkan setelah memberikan angket penilaian kepada dua dosen Jurusan Pendidikan Teknik Elektro yang ahli dalam materi Dasar Listrik dan Elektronika. Hasil uji validasi materi dapat dilihat pada Tabel 1.

Tabel 1. Hasil Uji Validasi Ahli Materi

\begin{tabular}{ccccc}
\hline & & \multicolumn{3}{c}{ Aspek yang dinilai } \\
\hline No & Validator & $\begin{array}{c}\text { Kualitas } \\
\text { Materi }\end{array}$ & $\begin{array}{c}\text { Kualitas } \\
\text { Pembelajaran }\end{array}$ & Jml \\
\hline 1 & $\begin{array}{c}\text { Ahli } \\
\text { materi 1 } \\
\text { Ahli }\end{array}$ & 53 & 18 & 71 \\
2 & 63 & 24 & 87 \\
\hline & Rerateri 2 & 58 & 21 & 79 \\
\hline
\end{tabular}

Aspek yang terdapat pada angket ahli materi terdiri atas aspek kualitas materi dan aspek kualitas pembelajaran.

Aspek kualitas materi memiliki 18 butir penilaian, dengan demikian skor ideal 
maksimal 72, skor ideal minimun 18 , rerata ideal 45 dan nilai simpangan baku ideal 9 . Konversi skor dari aspek kualitas materi dapat dilihat pada Tabel 2.

Tabel 2. Konversi Skor dari Aspek Kualitas Materi

\begin{tabular}{cc}
\hline $\begin{array}{c}\text { Interval Aspek } \\
\text { Kualitas Materi }\end{array}$ & Kategori Penilaian \\
\hline $61,2-72$ & Sangat Layak \\
$50,4-61,2$ & Layak \\
$39,6-50,4$ & Cukup Layak \\
$28,8-39,6$ & Kurang Layak \\
$18-28,8$ & Tidak Layak \\
\hline
\end{tabular}

Berdasarkan Tabel 2. diperoleh hasil skor untuk ahli materi 1 sebesar 53 dan ahli materi 2 sebesar 63 sehingga memiliki rerata skor 58. Rerata skor kemudian dicocokkan dengan Tabel 2 untuk mengetahui data kualitatifnya. Hasil skor pengujian materi pada aspek kualitas materi mendapatkan kategori "Layak".

Aspek kualitas pembelajaran memiliki 6 butir penilaian, dengan demikian skor ideal maksimal 24, skor ideal minimun 6, rerata ideal 15 dan nilai simpangan baku ideal 3. Konversi skor dari aspek kualitas pembelajaran dapat dilihat pada Tabel 3.

Tabel 3. Konversi Skor dari Aspek Kualitas Pembelajaran

\begin{tabular}{|c|c|}
\hline $\begin{array}{l}\text { Interval Aspek Kualitas } \\
\text { Materi }\end{array}$ & Kategori Penilaian \\
\hline $20,4-24$ & Sangat Layak \\
\hline $16,8-20,4$ & Layak \\
\hline $13,2-16,8$ & Cukup Layak \\
\hline $9,6-13,2$ & Kurang Layak \\
\hline $6-9,6$ & Tidak Layak \\
\hline
\end{tabular}

Berdasarkan Tabel 3 diperoleh hasil skor untuk ahli materi 1 sebesar 18 dan ahli materi 2 sebesar 24 sehingga memiliki rerata skor 21 . Rerata skor kemudian dicocokan dengan Tabel 25 untuk mengetahui data kualitatifnya. Hasil skor pengujian materi pada aspek kualitas pembelajaran mendapatkan kategori "Sangat Layak".
Kategori setiap aspek pada pengujian materi sudah diketahui, kemudian skor dikonversikan dalam bentuk persentase. Penilaian ahli materi dalam bentuk persentase, hasil persentase berbentuk diagram batang dapat dilihat pada Gambar 1.

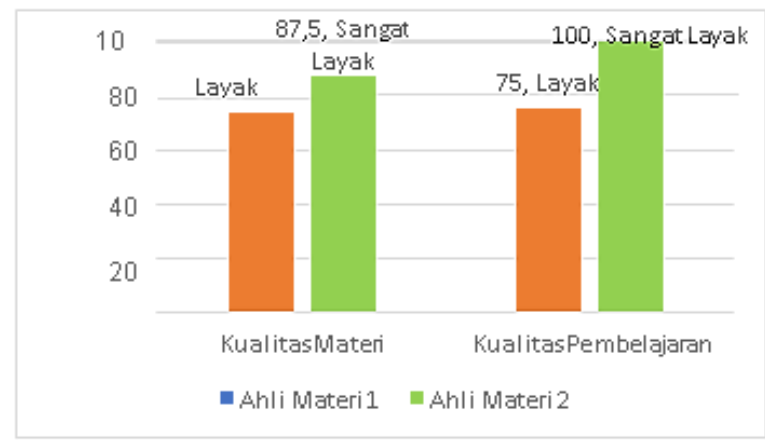

Gambar 1. Hasil Penilaian Kelayakan Materi

Hasil analisis data ahli media didapatkan setelah memberikan angket penilaian kepada dua dosen Jurusan Pendidikan Teknik Elektro yang ahli dalam media pembelajaran. Aspek yang terdapat pada angket terdiri atas aspek layout aplikasi, aspek tombol navigasi, aspek pengoperasian program, dan aspek kebermanfaatan. Hasil uji validasi media dapat dilihat pada Tabel 4 .

Tabel 4. Hasil Uji Validasi Media

\begin{tabular}{ccccccc}
\hline & \multicolumn{5}{c}{ Aspek yang dinilai } \\
\hline No Validator & $\begin{array}{c}\text { Layout } \\
\text { aplikasi }\end{array}$ & $\begin{array}{c}\text { Tombol } \\
\text { navigasi }\end{array}$ & $\begin{array}{c}\text { Peng- } \\
\text { operasian } \\
\text { program }\end{array}$ & $\begin{array}{c}\text { Keber- } \\
\text { manfaatan }\end{array}$ & Jml \\
\hline 1 & $\begin{array}{c}\text { Ahli } \\
\text { media 1 }\end{array}$ & 40 & 27 & 19 & 1 & 97 \\
& $\begin{array}{c}\text { Ahli } \\
\text { media 2 }\end{array}$ & 47 & 26 & 12 & 1 & 95 \\
& & & & 0 & \\
\hline & Rerata & 43,5 & 26,5 & 15,5 & 10,5 & 96 \\
\hline
\end{tabular}

Aspek layout aplikasi memiliki 13 butir penilaian, dengan demikian skor ideal maksimal 52, skor ideal minimun 13 , rerata ideal 32,5 dan nilai simpangan baku ideal 6,5. Konversi skor dari aspek layout aplikasi dapat dilihat pada Tabel 5. 
Tabel 5. Konversi Skor dari Aspek Layout Aplikasi

\begin{tabular}{ll}
\hline $\begin{array}{l}\text { Interval Aspek } \\
\text { Kualitas Materi }\end{array}$ & Kategori Penilaian \\
\hline $44,2-52$ & Sangat Layak \\
$36,4-44,2$ & Layak \\
$28,6-36,4$ & Cukup Layak \\
$20,8-28,6$ & Kurang Layak \\
$13-20,8$ & Tidak Layak \\
\hline
\end{tabular}

Berdasarkan Tabel 5 diperoleh hasil skor untuk ahli media 1 sebesar 40 dan ahli media 2 sebesar 47 sehingga memiliki rerata skor 43,5. Rerata skor kemudian dicocokan dengan Tabel 26 untuk mengetahui data kualitatifnya. Hasil skor pengujian media pada aspek layout aplikasi mendapatkan kategori "Layak".

Aspek tombol navigasi memiliki 7 butir penilaian, dengan demikian skor ideal maksimal 28 , skor ideal minimun 7 , rerata ideal 17,5 dan nilai simpangan baku ideal 3,5. Konversi skor dari aspek tombol navigasi dapat dilihat pada Tabel 6.

Tabel 6. Konversi Skor dari Aspek Tombol Navigasi

\begin{tabular}{ll}
\hline $\begin{array}{l}\text { Interval Aspek } \\
\text { Kualitas Materi }\end{array}$ & $\begin{array}{l}\text { Kategori } \\
\text { Penilaian }\end{array}$ \\
\hline $23,8-28$ & Sangat Layak \\
$19,6-23,8$ & Layak \\
$15,4-19,6$ & Cukup Layak \\
$11,2-15,4$ & Kurang Layak \\
$7-11,2$ & Tidak Layak \\
\hline
\end{tabular}

Berdasarkan Tabel 6 diperoleh hasil skor untuk ahli media 1 sebesar 27 dan ahli media 2 sebesar 26 sehingga memiliki rerata skor 26,5. Rerata skor kemudian dicocokan dengan Tabel 27 untuk mengetahui data kualitatifnya. Hasil skor pengujian media pada aspek tombol navigasi mendapatkan kategori "Sangat Layak".

Aspek tombol navigasi memiliki 5 butir penilaian, dengan demikian skor ideal maksimal 20, skor ideal minimun 5, rerata ideal 12,5 dan nilai simpangan baku ideal 2,5. Konversi skor dari aspek pengoperasian program dapat dilihat pada Tabel 7.
Tabel 7. Konversi Skor dari Aspek Pengoperasian Program

\begin{tabular}{ll}
\hline $\begin{array}{c}\text { Interval Aspek } \\
\text { Kualitas Materi }\end{array}$ & Kategori Penilaian \\
\hline $17-20$ & Sangat Layak \\
$14-17$ & Layak \\
$11-14$ & Cukup Layak \\
$8-11$ & Kurang Layak \\
$5-8$ & Tidak Layak \\
\hline
\end{tabular}

Berdasarkan Tabel 7 diperoleh hasil skor untuk ahli media 1 sebesar 19 dan ahli media 2 sebesar 12 sehingga memiliki rerata skor 15,5. Rerata skor kemudian dicocokan dengan Tabel 28 untuk mengetahui data kualitatifnya. Hasil skor pengujian media pada aspek pengoperasian program mendapatkan kategori "Layak".

Aspek kebermanfaatan memiliki 3 (tiga) butir penilaian, dengan demikian skor ideal maksimal 12, skor ideal minimun 3, rerata ideal 7,5 dan nilai simpangan baku ideal 1,5. Konversi skor dari aspek pengoperasian program dapat dilihat pada Tabel 8 .

Tabel 8. Konversi Skor dari Aspek Pengoperasian Program

\begin{tabular}{ll}
\hline $\begin{array}{l}\text { Interval Aspek Kualitas } \\
\text { Materi }\end{array}$ & Kategori \\
\hline $10-12$ & Penilaian \\
$8-10,2$ & Sangat Layak \\
$7-8,4$ & Layak \\
$5-6,6$ & Cukup Layak \\
$3-4,8$ & Kurang Layak \\
\hline
\end{tabular}

Berdasarkan Tabel 8 diperoleh hasil skor untuk ahli media 1 sebesar 11 dan ahli media 2 sebesar 10 sehingga memiliki rerata skor 10,5. Rerata skor kemudian dicocokan dengan Tabel 29 untuk mengetahui data kualitatifnya. Hasil skor pengujian media pada aspek pengoperasian program mendapatkan kategori "Sangat Layak".

Kategori setiap aspek pada pengujian media sudah diketahui, kemudian skor dikonversikan dalam bentuk persentase, hasil 
persentase pengujian media berbentuk diagram batang dapat dilihat pada Gambar 2.

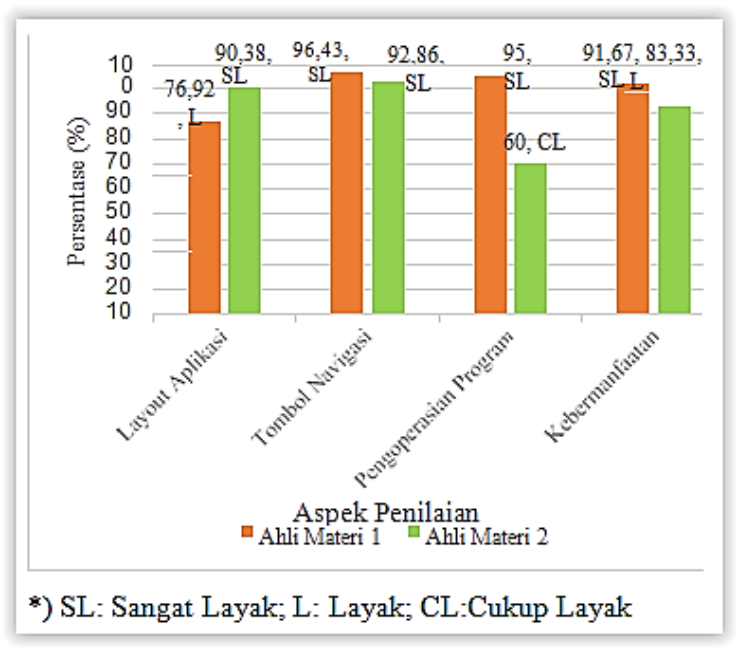

Gambar 2. Hasil Penilaian Kelayakan Media

Uji pengguna dilakukan dengan memberikan angket ke 20 responden. Angket penilaian tersebut terdiri dari tiga aspek yaitu aspek layout aplikasi, aspek, aspek tombol navigasi, dan aspek kebermanfaatan aplikasi.

Penilaian pada aspek layout aplikasi mendapatkan skor total semua responden sebanyak 664. Skor total 664 dibagi dengan jumlah responden (20 responden) sehingga didapat rerata skor sebesar 33,30. Rerata skor kemudian dibandingkan dengan skor maksimal sehingga diperoleh persentase sebesar 75,45\%, sehingga mendapatkan kategori "Layak".

Penilaian pada aspek tombol navigasi mendapatkan skor total semua responden sebanyak 484. Skor total 484 dibagi dengan jumlah responden (20 responden) sehingga didapat rerata skor sebesar 24,20. Rerata skor kemudian dibandingkan dengan skor maksimal sehingga diperoleh persentase sebesar 75,63\%, sehingga mendapatkan kategori "Layak".

Penilaian pada aspek kebermanfaatan aplikasi mendapatkan skor total semua responden sebanyak 483. Skor total 483 dibagi dengan jumlah responden (20 responden) sehingga didapat rerata skor sebesar 24,15. Rerata skor kemudian dibandingkan dengan skor maksimal sehingga diperoleh persentase sebesar 75,47\%, sehingga mendapatkan kategori "Layak".

Rerata skor dari aspek layout aplikasi, aspek tombol navigasi, dan aspek kebermanfaatan aplikasi dijumlah untuk mengetahui uji kelompok kecil secara keseluruhan. Berdasarkan data di atas, diperoleh total total rerata skor 81,55 dari total skor maksimal sebesar 108. Sehingga persentase tingkat kelayakan media pembelajaan secara keseluruhan adalah 75, 51\% dengan kategori "Layak". Grafik hasil uji pengguna dapat dilihat pada Gambar 3.

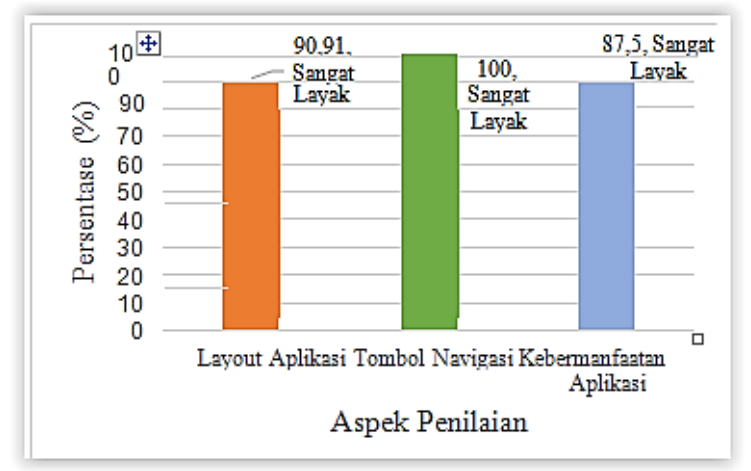

Gambar 3. Grafik Hasil Uji Pengguna

\section{SIMPULAN}

Pertama, unjuk kerja pada penelitian media pembelajaran berbasis android untuk kompetensi dasar pengukuran listrik secara keseluruhan dinyatakan "Sangat Baik". Hal tersebut dapat dilihat pada pengujian kotak hitam (black box testing). Hasil pengujian black box yang ditinjau dari indikator kesesuaian aplikasi dan ketepatan navigasi berjalan normal atau tidak ada kesalahan.

Kedua, kelayakan media pembelajaran interaktif berbasis android untuk kompetensi dasar pengukuran listrik diketahui dari kegiatan validasi yang dilakukan para ahli dengan cara menilai aspek- aspek produk. Hasil validasi didapat dari validator materi dan validator media. Berdasarkan validator materi pada aspek kualitas materi didapat rerata $80,56 \%$, aspek kualitas pembelajaran didapat rerata 87,50\%. Keseluruhan penilaian kelayakan materi didapat 
rerata 82,29\%, dengan kategori "Layak". Berdasarkan validator media pada aspek layout aplikasi didapat rerata $83,65 \%$, aspek tombol navigasi didapat rerata $94,64 \%$, aspek pengoperasian program didapat rerata $77,50 \%$, dan aspek kebermanfaatan didapat rerata 87,5\%. Keseluruhan penilaian kelayakan media didapat rerata $85,71 \%$, dengan kategori "Sangat Layak".

Terakhir, tanggapan pengguna terhadap media pembelajaran interaktif berbasis android untuk kompetensi dasar pengukuran listrik yang dilakukan peneliti didapat berdasarkan pengguna awal, pengguna kelompok kecil, dan pengguna akhir.

Pada pengguna awal respondennya adalah guru. Hasil penilaian pengguna awal keselurahan didapat 92,59\%, dengan kategori "Sangat Layak". Pada pengguna kelompok kecil keseluruhan didapat $78,70 \%$, dengan kategori "Layak". Dan terakhir pada pengguna akhir keseluruhan didapat $75,51 \%$ dengan kategori "Layak". Selain memberikan tanggapan dengan mengisi angket yang diberikan. Peserta didik juga mengisi komentar dan saran. Dari 25 responden (uji kelompok kecil dan pengguna akhir) terdapat $48 \%$ memberikan komentar positif dan $12 \%$ memberikan komentar negatif. Dan 40\% memberikan saran yang bersifat memperbaiki produk.

\section{DAFTAR RUJUKAN}

Amir, Y. h., \& Apriani, D. (2011). Guru yang Melek Teknologi Informasi dan Komunikasi. Cermin Edisi 048,14-18.
BPHN. (1990). Peraturan Pemerintah Republik Indonesia Nomor 29 Tahun 1990 tentang Pendidikan Menengah.

Kartikasari, G. (2016). Pengaruh Media Pembelajaran Berbasis Multimedia Terhadap Motivasi dan Hasil Belajar Materi Sistem Pencernaan Manusia: Studi Eksperimen pada Peserta didik Kelas V MI Miftahul Huda Pandantoyo. Jurnal Dinamika Penelitian, 1,63 .

Keputusan Direktur Jenderal Pendidikan Dasar dan Menengah Nomor 330/D.D5/KEP/KR/2017 tentang Kompetensi Inti dan Kompetensi Dasar mata Pelajaran Muatan Nasional (A), Muatan Kewilayahan (B), Dasar Bidang Keahlian (C1), Dasar Program Keahlian (C2), dan Dasar Kompetensi Keahlian (C3).

Lee, W. W. \& Owens, D. L. (2004). Multimedia- based Instructional Design: Computer-based Training, Webbased Training, Distance Broadcast Training, Performance-based Solutions 2nd ed. San Francisco: Pfeiffer.

Sugihartono, dkk (2015). Psikologi Pendidikan. Yogyakarta: UNY Press.

Tung, K.Y. (2017). Desain Instruksional: Perbanding Model \& Implementasinya. Yogyakarta: Andi. 